\title{
Research on New Thinking of Culture-Oriented English Teaching
}

\author{
Junye Yang \\ The College of Arts and Science Yunnan Normal University, Kunming Yunnan, 650222, China
}

Keywords: Cultural orientation, English teaching, New thinking

\begin{abstract}
In studying on the current college English teaching in China, it is found that the teaching practice of cultural status is limited, seriously restricting the cultivation of students' English cultural thinking and the strengthening of the intercultural communication ability. Therefore, it is important to start from the cultural orientation mode, form a new thinking of culture-oriented English teaching, promote the improvement of English teaching quality, and ensure the practical effect of students' English cultural literacy.
\end{abstract}

\section{Introduction}

The main goal of English teaching in colleges and universities is to cultivate the student's ability of intercultural communication, ensure that students' English knowledge can be applied to the actual communication activities, provide the corresponding support for the students' career development and assist. So in foreign language teaching, in addition to teach students the basic knowledge of English language, but also strengthen the attention to culture teaching, introducing culture-oriented teaching new thinking in the teaching, to strengthen the influence of English culture teaching, guarantee the cultivation of the students' cross-cultural communication ability, promote students' English comprehensive quality constantly strengthened.

\section{Culture-oriented Teaching Mode}

The cultural system itself contains the language, the development of culture will have an important influence on the language, and the language will play an important role in promoting the development of culture. In the process of participating in foreign language learning activities, the main learning objective is to master the application skills of language and the understanding of the cultural meaning of the target language, thus forming intercultural communication competence. So for English teaching, English teachers in the teaching activities, to realize the importance of cultural knowledge teaching in English teaching activities through the contrast of Chinese and western cultural differences, and to culture teaching into the teaching of listening, speaking, reading and writing, and promote effectively train students' language application ability. Culture-oriented teaching mode is based on the teaching requirements and teaching mode of teaching view, specifically refers to in the teaching activities, teachers in the implementation of English training for students through the comparison between Chinese and western culture, let the student through the system of learning and exploration can form consciousness and ability to cross-cultural communication, to achieve the cultivation of student's English application abilities, make the students to be the cross-cultural communication. Culture-oriented teaching mode should pay attention to the application of it into the whole process of teaching activities, both in the phonetic teaching, grammar teaching and discourse and cognitive mode of teaching organization activities, to strengthen the application of cultural comparison, ensure that students in the learning process can be through the linguistic phenomenon in language learning, enhance the students' thinking and cultural cognitive mode, promote the students' language communication ability to further improve. 


\section{Cultural Oriented English Teaching Thinking Innovation}

English quality education for college students to work requirements and the current basic situation of cultivating students' English quality, in the reform on college English teaching activities in the process of innovation, should start from cultural orientation to form a new teaching thinking and develop teaching culture field of vision, strengthen the quality of English teaching practice. Specifically, the innovation of English teaching thinking under the guidance of culture-oriented model is reflected in the following aspects.

\subsection{Reposition the Teaching Angle with Cultural Orientation}

College English knowledge input of English teaching in the middle and primary schools exist obvious differences in the teaching activities, in order to guarantee the students' English learning, teachers can't focus on the present English knowledge, should also be from the perspective of cultural transmission to organize activities for English teaching. In general, students before enter the university campus, already have a certain basis of English learning, teachers should combine the characteristics of college students' English learning to explore English culture education and the organic integration of knowledge of English, English culture as English knowledge into the teaching activities, play the guiding role of culture, let the students in the process of English learning to form a more comprehensive understanding of English culture, ensure that under the action of cultural spirit to guide the students' English learning effect can be significantly enhanced. At the same time, the college teachers to culture as an important reference standard on all aspects of English teaching reform and innovation, and compare the differences between Chinese and western cultural knowledge as a breakthrough point of the teaching goal of teaching reform plan, and the reasonable choice of teaching content, in the cultural atmosphere under the excitation of can enhance students' English learning motivation, promote the enhancement of the overall learning effect, highlight the scientific nature and effectiveness of college English teaching activities.

\subsection{Promote the Diversified Development of Teaching Activities at Different Teaching Levels with the Help of Culture}

Culture-oriented English teaching the formation of new thinking and the diversification of teaching activities is also a connection, so according to the need of different teaching levels, explore diversified teaching organization activities, first of all, in the interest excitation level, the teacher wants to introduce various kinds of teaching methods to enhance teaching interesting and implementation to inspire students' learning interest and learning enthusiasm. In the process of practical teaching activities, the teacher will multicultural guidance as core design connotation rich teaching activities, let the student be able to complete the knowledge of English in the cultural atmosphere of the study, the benefit of the influence of the culture, for the students from the perspective of cultural diversity to strengthen the understanding and the understanding of English knowledge to provide the corresponding support. Second, teachers in the teaching activities to break through the limitation of teaching material of the text, with the support of information technology to strengthen the application of pluralistic culture, enrich the teaching content, form surface of culture in English teaching, guarantee the students' study effect. Such as teachers can be collected on the Internet rich teaching materials related to the contrast between Chinese and western culture, and the teaching material into many aspects of teaching activities, ensure that students can explore the combination of cultural form a clear understanding of western culture and its cultural differences, and for the cultivation of the students' cross-cultural communication ability to lay a solid foundation. In the process of introduction of rich cultural material, the teacher should also realize that culture is changing and developing, so teachers can try to introduce the latest western culture thought auxiliary to carry out teaching activities, to enhance students' understanding of western culture and cognition, and for the cultivation of the students' knowledge of English application ability to lay the solid foundation. Finally, based on the demand of culture-oriented teaching mode, teachers should combine the cultural contrast and application to innovation of teaching methods, shift the 
force-feeding teaching way, using a variety of teaching methods of the application of communication and interaction between teachers and students, promote the spread of culture in the communication between teachers and students, on the basis of good teaching atmosphere also can really play culture education function, implementation to the cultivation of students' comprehensive quality.

\section{The Practical Application of Culture-Oriented Teaching Mode in College English Teaching}

English teaching activities in colleges and universities to reform the innovation, the main or culture-oriented teaching mode applied in college English teaching activities, provide guidance to teachers' teaching activities. So college English teachers should start from the nature of cultural interaction, based on the realistic requirement of cultivating students' intercultural communicative competence exploration culture-oriented teaching mode in the practical application of English teaching activities, promote college English teaching advantages highlighted. In this research, from the cultivation of university students' English listening and speaking ability as the breakthrough point to carry on the analysis, to explore the application of culture-oriented teaching mode in English teaching, can hope to other English teachers organize teaching activities provide a good reference.

\subsection{The Teaching Material is Closely Combined with the English Culture in the Textbook}

Nowadays, English textbooks in colleges and universities often involve some aspects of English culture, which can provide corresponding support for the application of culture-oriented teaching mode. So the requirements for college English teaching activities, teachers in the process of organization to carry out English teaching practice to fully tapped on the cultural elements in the teaching material, and timely supplement the cultural background knowledge, let the students before class preview stage to make a study and analysis of related cultural knowledge to provide the corresponding auxiliary classroom teaching activities. Before formal conduct listening teaching activities, teachers can let students will study of culture research results and related cultural phenomenon to show, teachers guide students from the perspective of cultural differences of comparative analysis, and then gradually develop English listening teaching activities, can guarantee the to fully understand the cultural background, on the basis of improving the students' listening learning.

Such as teachers in college English listening teaching, a hearing article, "The Origin of Christmas" pre-course reading activities, combined with The specific content of The hearing training organization students related to The Origin of The "Christmas" culture of study, students on The Origin of The "Christmas" involved "The Mass of Christ", "The Holy Spirit made Mary pregnant and Mary gave birth to Jesus." The cultural content of "Santa Claus", "Holly and Mistletoe" forms a clear understanding [3]. On this basis, the teachers lead students to participate in the hearing training, in the cultural background knowledge, students can better understand the listening discourse, obtain good hearing effect.

\subsection{Situation Creation, Strengthen the Application of Multimedia Teaching}

Based on culture-oriented English teaching reform, teachers in order to show students in the teaching activities more cultural background and cultural content, lets the student in learning English cultural knowledge in the process of the formation of English knowledge exploration interest, enhance students' English learning enthusiasm and initiative, on the basis of cultural transmission, to create conditions for the cultivation of the students' English comprehensive quality. In the teaching activities, in order to be able to cross-cultural English listening ability of students for effective training, should be combined with the application of multimedia technology to explore the creation of teaching situation, lets the student in a particular cultural situation in form of the good experiences of English learning, make sure to further improve the quality of English listening teaching.

For example, in the process of university students' English learning, often involves the content of the Chinese and western dining etiquette, in order to make students combined with the cultural background knowledge of this part of the form image intuitive understanding, ensure that students of 
English training effect, can use the way of multimedia display video, to show students the Chinese movie life in western countries, such as The Joy Luck Club, and Pushing Hands, etc., which on the one hand, with the help of a film situation creation to training students' ability in English listening, on the one hand, through the contrast of Chinese and also let the student to dining etiquette difference form more clear understanding, to ensure the students' English learning effect.

\subsection{Strengthen the Application of Network Resources, Enrich Classroom Teaching Content}

Traditional English classroom teaching activity, English culture teaching resources, strong enough to support culture-oriented English teaching activity Settings, greatly limits the optimization of English teaching activities, is not conducive to the strengthening of the students' English literacy and the cultivation of intercultural communicative competence. And in information technology is widely used in colleges and universities in the new period under the background in the field of English education, college English teachers in based on culture-oriented English teaching needs to reform the teaching activities in the process of innovation, can strengthen the application of network English culture resources, realize the network of the integration of English culture resources, enriching the content of classroom teaching, and realize the effective complement to classroom teaching activities.

For example, in the social background of deepening economic globalization, the integration of large Numbers of foreigners into our country has exerted an important influence on the cultural exchange between China and the west, and the network English cultural resources have become more and more abundant. In the process of actual organizations to carry out teaching activities, teachers on the one hand, can search related English culture education resources on the Internet into classroom teaching activities, enhance the classroom teaching activities of the culture, realize to the cultivation of students' English comprehensive quality, ensure that students cross-cultural communication ability training effect, on the other hand, the school also can build communication platform, actively inviting foreigners register account on the platform in the society, and the university students to use English for communication and exchanges, and in the communication consciously strengthen the contrastive analysis of Chinese and western culture, to help foreigners to understand Chinese at the same time, also enhanced the student to the understanding and the understanding of western culture, highlight the teaching effectiveness. At the same time, with the aid of real-time communication and exchanges with foreign friends, students' English listening ability and ability to cross-cultural communication will also get the proper training, talents training in colleges and universities work produce certain positive impact. So college English teachers should further strengthen the application of network education resources, under the support of network education resources based on culture oriented teaching mode for English teaching activities to reform the innovation, strengthen the teaching influence, to guarantee the steady development of the talent training work.

\section{Conclusions}

Based on the analysis of the above, in the college English teaching practice, new thinking, actively build culture-oriented English teaching to reform the innovation, organization of teaching activities can deepen the cultural connotation of English teaching, the implementation of the cultivation of the students' cross-cultural communicative competence and the strengthening of knowledge application ability, to lay a good foundation for students to better learning and development future. Based on this, actively explore the reform of English teaching in colleges and universities in the process of development, must strengthen the recognition of culture-oriented English teaching, and as the breakthrough point from which to explore the measures of teaching reform, the comprehensive optimization of auxiliary personnel training work.

\section{References}

[1] Chang Lu. Research on the teaching reform of tourism English based on cultural orientation -taking the tourism English course of Beijing City College as an example, Education, 
2016(12):00109-00109.

[2] Li Rong, Liu Xiaoling. The application of culture-oriented teaching mode in college English teaching, English square, 2015(9):143-144.

[3] Li Baihong. Research and practice of college English teaching mode guided by cultural value, Modern communication: academic edition. 2016(5):181-182.

[4] Ding Mingjie. Study on the teaching mode of oral English based on economic culture, Accounting of township enterprises in China, 2016(8):258-259.

[5] Liu Qin, Jin Liyuan. The feasibility study of college English culture teaching based on output, Modern communication: academic edition, 2017(22):5-6. 